\title{
Analisis Kandungan Klorin pada Beras yang Beredar Di Pasar Tradisional Makassar Dengan Metode Argentometri Volhard
}

\author{
Siti Aminah*1); Ismail Marzuki ${ }^{2)}$; Asmi Rasyid ${ }^{3)}$ \\ ${ }^{1)}$ Staf bidang Pertanian Dinas Perikanan dan Pertanian Kota Makassar \\ ${ }^{2}$ Staf Dosen pada Prodi Teknik Kimia, Fakultas Teknik Univ. Fajar, Makassar \\ ${ }^{3}$ Staf Dosen Pada Jurusan Farmasi Univ. Indonesia Timur, Makassar
}

\begin{abstract}
ABSTRAK
Senyawa klorin berpungsi untuk memutihkan dan mengkilapkan material seperti beras dan biji-boijian lainnya. Penggunaan klorin dalam produksi beras melalui penggilingan memungkinkan dilakukan untuk tujuan pemutihan dan pengkilapan permukaan. Meskipun demikian penggunaan klorin pada bahan pangan seperti beras tidak boleh digunakan karena berpotensi mengganggu dan merusak usus, lambung dan organ pencernaan lainnya termasuk berpotensi memicu kanker hati dan ginjal.Tujuan untuk mengetahui keberadaan dan kadar klorin yang dihitung sebagai Asam Hipoklorin dengan metode Argentometri Volhard. Pengujian dilakukan delapan sampel beras yang diambil dari beberapa pasar di Makassar dengan teknik porposive sampling, dengan metode kualitatif dan kuantitatif. Analisis kualitatif klorin dilakukan menggunakan larutan Kalium Iodida, Asam Klorida, dan Amilum, hasil dinyatakan posistif terbentuknya warna biru pada larutan uji menunjukkan bahwa sampel ini mengandung klorin. Hasil analisis kualitatif ini menunjukkan bahwa 3 (tiga), yakni sampel A, E dan $\mathrm{H}$ dari 8 (delatan) sampel beras tersebut positif mengandung klorin, sehingga tidak layak di konsumsi karena mengandung bahan kimia (Peraturan Menteri Pertanian Nomor 32/PERMENTAN/ OT.140/3/2007). Ketiga sampel yang positif ini selanjutnya dilakukan analisis kuantitatif. Hasil analisis kuantitatif diperoleh kadar rata-rata klorin dalam sampel A adalah 28,85 ppm, sampel $\mathrm{E}$ adalah $34,13 \mathrm{ppm}$ dan sampel $\mathrm{H}$ adalah $28,84 \mathrm{ppm}$. Ketiga sampel ini tidak layak dikonsumsi karena melebihi nilai ambang batas yang dipersyaratkan menurut Permenkes RI No.772/ Menkes/Per/XI/88.
\end{abstract}

Kata kunci : klorin, Argentometri, beras, pasar Tradisional.

\section{PENDAHULUAN}

Tanaman padi diperkirakan berasal dari Bangladesh di Asia selatan. Padi yang digiling menjadi beras merupakan serealia yang sangat penting dan merupakan bahan pangan pokok bagi setengah penduduk bumi pada umumnya dan sebagian besar rakyat Indonesia pada khususnya. Tanaman padi merupakan rumputan tahunan yang menghasilkan sejumlah cabang-cabang halus yang berakhir dengan butiran tunggal yang terbungkus oleh kulit. Konsumsi beras dalam bentuk nasi merupakan kebutuhan pokok yang tidak dapat dipungkiri. Sebanyak 75\% masukan kalori harian masyarakat di negara-negara Asia yang penduduknya padat, khususnya Bangladesh, Myanmar, Kamboja, Cina, Indonesia, Korea, Laos, Filipina, Srilangka, Thailand, dan Vietnam berasal dari beras. Lebih dari $50 \%$ penduduk dunia tergantung pada beras sebagai sumber kalori utama. Keterikatan pada beras sebagai bahan pokok dikarenakan pengolahannya mudah dan cepat, memberi kenikmatan pada saat menyantap, dan aman dari segi kesehatan. Namun, keamanan ini terusik oleh adanya isu keberadaan bahan kimia berbahaya pada beras.

Beras merupakan bahan makanan pokok bagi sebagian besar rakyat Indonesia dan penduduk daerah tropik lainnya. Beras adalah butir padi yang telah dibuang kulit luarnya (sekamnya) yang menjadi dasar dedak kasar. Dedak halus berasal dari lapisan-lapisan permukaan biji beras, misalnya lapisan aleuron, lembaga dan beberapa lapis sel biji beras yang terlepas waktu proses penggilingan. Bila dedak kasar tidak dapat dikonsumsi oleh manusia maka dedak halus masih dapat dijadikan bahan makanan untuk konsumsi. Dedak kasar biasanya masih dapat dimanfaatkan untuk bahan bakar atau dipergunakan sebagai campuran bahan pakan ternak dan unggas atau ikan.

Kandungan beras terdiri atas bagian gabah yang diperoleh setelah penggilingan yang kemudian disebut beras giling, mengandung $78 \%$ karbohidrat dan $7 \%$ protein. Sebagian terbesar karbohidrat dalam beras adalah pati (85-90\% dari berat kering), sebagian kecil pentosan $(2,0-2,5 \%)$ dan gula $(0,6-1,4 \%)$. Pati beras, sebagaimana pati pada umumnya terdiri atas rangkaian satuan-satuan $\alpha$-D-glukosa yang terdiri atas fraksi berantai lurus yaitu amilosa dan fraksi berantai cabang yaitu amilopektin. Amilopektin merupakan fraksi utama pada beras. Berdasarkan kadar amilosanya, beras (tidak termasuk beras ketan) dapat dikelompokkan menjadi beras beramilosa sedang $(20-25 \%)$ dan beras beramilosa tinggi yang lazim disebut beras keras (25 -

\footnotetext{
*11Korespondensi penulis: Siti Aminah, Telp. 08121660403324, Email : staminah1972@gmail.com
} 
33\%). Perbandingan berat amilopektin dan amilosa dalam beras merupakan faktor terpenting dalam penentuan mutu rasa dan tekstur nasi. makin tinggi kadar amilosa, volume nasi yang diperoleh makin besar tanpa kecenderungan mengempes, karena amilosa mempunyai kemampuan retrogradasi yang lebih besar. Penyusun utama kedua pada beras adalah protein. Beras pecah kulit mengandung protein sekitar $8 \%$ pada kadar air $14 \%$ dan sekitar 7\% pada beras giling. Penyusun selanjutnya pada beras adalah lipida. Kadar lemak pada beras pecah kulit adalah 2,4-3,9\% dan 0,3-0,6\% pada beras giling. Vitamin pada beras yang terutama ialah tiamin, riboflavin, niasin, dan piridoksin, masing-masing terdapat dalam $4 \mu \mathrm{g} / \mathrm{g} ; 0,6 \mu \mathrm{g} / \mathrm{g}$ dan $50 \mu \mathrm{g} / \mathrm{g}$. Beras mengandung vitamin A dan vitamin D. Mineral pada beras terutama terdiri atas unsur-unsur fosfor, magnesium, dan kalium. Selain itu terdapat kalsium, natrium, silika dan besi.

Warna beras berbeda-beda karena adanya perbedaan genetik, akibat perbedaan gen yang mengatur warna aleuron, warna endospermia dan komposisi pati pada endospermia. Warna beras yang umum dikembangkan di Indonesia terdiri atas: a. beras biasa, berwarna putih agak transparan karena memiliki sedikit aleuron dan kandungan amilosa umumnya sekitar 20\%. Beras ini mendominasi pasar beras; b. beras merah, akibat aleuronnya mengandung gen yang memproduksi antosianin yang merupakan sumber warna merah atau ungu; c. beras hitam, sangat langka, disebabkan aleuron dan endospermia memproduksi antosianin dengan intensitas tinggi sehingga berwarna ungu pekat mendekati hitam; d. beras ketan berwarna putih, tidak transparan, seluruh atau hampir seluruh patinya merupakan amilopektin; e. Ketan hitam, merupakan versi ketan dari beras hitam. Beberapa jenis beras mengeluarkan aroma wangi bila ditanak (misalnya Cianjur, Pandanwangi atau Rajalele). Bau ini disebabkan beras melepaskan senyawa aromatik yang memberikan efek wangi. Sifat ini diatur secara genetik dan menjadi objek rekayasa genetika beras.

Menurut Peraturan Menteri Pertanian Nomor 32/PERMENTAN/OT.140/3/2007 tentang pelarangan penggunaan bahan kimia berbahaya pada proses penggilingan padi, huller, dan penyosohan beras menyatakan bahwa beras adalah hasil utama dari proses penggilingan gabah hasil tanaman padi (Oryza sativa L.) yang seluruh lapisan sekamnya terkelupas dan seluruh atau sebagian lembaga dan lapisan bekatulnya telah dipisahkan. Dalam peraturan ini juga disebutkan bahwa beras yang diperoleh melalui penggilingan padi, huller, dan penyosohan beras dilarang menggunakan bahan kimia berbahaya.

Hasil pemeriksaan gabungan antara Dinas Perindustrian, Perdagangan, Koperasi, dan Pariwisata, Dinas Kesehatan, Dinas Pertanian, dan Dinas Pengawasan Obat dan Makanan, telah ditemukan adanya klorin pada beras di beberapa kota di Indonesia (Medan, Tangerang, Banten, Bandung, Bekasi, Bogor dan Manado) setelah uji laboratorium (Yus, 2007).

Secara ilmiah, klorin adalah bahan kimia yang berfungsi sebagai desinfektan atau pembunuh kuman. Zat kimia ini bersifat racun bagi tubuh yang dalam perdagangan Internasional disimbolkan dengan lambang tengkorak. Penggunaan klorin adalah bagian dari praktik curang sejumlah pedagang beras dalam upaya menaikkan harga. Klorin digunakan pada beras yaitu sebagai anti jamur dan efek putih dengan cara mencampurkan ke dalam beras melalui proses perendaman maupun penyemprotan sehingga beras menjadi putih, bersih, mengkilap, tidak mudah rusak dan memiliki nilai jual yang tinggi. Padahal klorin biasa digunakan untuk memutihkan kain. Klorin yang tertelan dapat menimbulkan nyeri dan inflamasi pada mulut, kerongkongan, lambung, dan perut, serta iritasi membran mukosa perut dan pernapasan. Dalam jangka panjang bisa menyebabkan kanker hati dan ginjal.

Klorin digunakan secara meluas dalam pembuatan produk sehari-hari (dalam bentuk acid dan garam hipoklorus). Klorin digunakan untuk membunuh bakteri pada bekal minuman dan kolam renang. Digunakan secara meluas di dalam pembuatan kertas, fungsi antiseptik, racun serangga, bahan cat lukisan, produk-produk petroleum, plastik, obat-obatan, tekstil, pelarut, dan banyak produk lainnya. Dipasaran klorin banyak diperjualbelikan dalam bentuk kalsium hipoklorida atau yang dikenal para pedagang kimia sebagai kaporit. Kaporit ini yang umum digunakan sebagai pemutih.

Permasalahan yang muncul dari uraian di atas adalah apakah beras yang beredar di pasar Tradional Makassar tidak mengandung bahan tambahan termasuk bahan kimia sehingga aman untuk dikonsumsi. Penelitian ini bertujuan menganalisis klorin pada beras yang beredar di pasar tradicional Kota Makassar dengan menggunakan metode análisis kualitatif (penggunaan reagen kimia spesifik) dan metode kuantitatif untuk menentukan kadar klorin dalam beras menggunakan cara Argentometri Volhard. 


\section{METODE PENELITIAN}

\section{a. Alat dan Bahan}

Beberapa peralatan yang digunakan diantaranya: batang pengaduk, blender, cawan porselin, seperangkat alat gelas, mikro Buret, sendok tanduk, Thermometer, timbangan analitik. Bahan yang dugunakan adalah: Aqua Destillata, Asam Klorida p.a., Asam Nitrat p.a., sampel beras, Feri Amonium Sulfat, Kalium Iodida, Kalium Kromat, Kalium Tiosianat, Larutan Kanji/ Amilum, Natrium Klorida p.a., Nitrobenzen dan Perak Nitrat $\left(\mathrm{AgNO}_{3}\right)$.

\section{b. Pengambilan dan Penyiapan Sampel}

Sampel beras sebanyak 8 (delapan) jenis diperoleh dari beberapa Pasar Tradisional di Kota Makassar. Pengambilan sampel dengan teknik porposive sampling yaitu sampel berupa beras yang dicurigai mengandung klorin dengan ciri-ciri fisik berwarna putih bersih, lebih mengkilap, dan licin). Sampel beras disiapkan dengan cara mengolah sampel sesuai prosedur sampel beras dihaluskan menggunakan alat penghancur (blender), kemudian sampel halus di buat dalam bentuk larutan dengan cara ditimbang $\pm 1 \mathrm{~g}$ sampel beras yang telah dihaluskan dalam gelas piala, ditambahkan $10 \mathrm{ml}$ Aquadest, dikocok, didiamkan selama 10 menit lalu disaring.

\section{c. Prosedur Kerja dan Metode Analisis}

Analisis Kualitatif untuk menentukan komponen klorin dalam sampel beras dilakukan dengan prosedur: filtrat dipipet $2 \mathrm{ml}$, dimasukkan ke dalam tabung reaksi kemudian ditambahkan larutan Kalium Iodida dan Asam Klorida encer, kemudian ditambahkan larutan kanji, jika terjadi warna biru berarti positif mengandung klorin. Analisis Kuantitatif untuk menentukan kadar klorin setiap sampel yang positif mengandung klorin, dilakukan dengan terlebih dahulu membuat larutan baku $\mathrm{AgNO}_{3} 0,02 \mathrm{~N}$, lalu larutan tersebut dibakukan, membuat larutan baku KCNS 0,02 N, selanjutnya dibakukan.

Penentuan kadar klorin dilakukan dengan prosedur: ditimbang seksama sampel beras yang telah dihaluskan sebanyak \pm 5 gram, dimasukkan ke dalam gelas piala, ditambahkan $15 \mathrm{ml}$ Aqua dest, diaduk, didiamkan 10 menit dan disaring kedalam erlenmeyer $250 \mathrm{ml}$. Residu ditambahkan Aqua Dest $15 \mathrm{ml}$, diaduk, didiamkan 10 menit dan disaring kedalam Erlenmeyer $250 \mathrm{ml}$ yang telah berisi filtrat pertama. Filtrat lalu ditambahkan $3 \mathrm{ml} \mathrm{HNO}_{3} 6 \mathrm{~N}$. Kemudian ditambahkan $\mathrm{AgNO}_{3}$ standar dari dalam buret sebanyak $5 \mathrm{ml}$. Lalu ditambahkan $3 \mathrm{ml}$ nitrobenzen dikocok kuat untuk mengkoagulasi endapan, lalu ditambahkan $1 \mathrm{ml}$ indikator besi(III). Larutan tersebut dititrasi dengan perak nitrat yang tersisa dengan larutan KSCN 0,02 N standar sampai larutan tepat berwarna kemerahan yang permanen.

\section{HASIL DAN PEMBAHASAN}

Analisis kualitatif perlu dilakukan terlebih dahulu sebelum dilakukan penentuan kadar klorin dalam setiap sampel. Tujuan dari análisis ini adalah análisis awal untuk melihat apakah sampel tersebut terkontaminasi (mengandung) klorin atau tidak. Tujuan lain dari análisis kualitatif adalah untuk efisiensi prosedur dan meminimalkan penggunaan bahan agar lebih akenomis. Hasil analisis kualitatif untuk menentukan 8 macam sampel beras apakah positifmengandung klorin atau tidak, sebagaimana disajikan pada Tabel 1, berikut:

Tabel 1. Hasil Analisis kualitatif keberadaan Klorin pada sampel beras yang beredar di Pasar Tradisional Kota Makassar

\begin{tabular}{|c|c|c|c|c|c|}
\hline K. Sampel & Pereaksi & Pengamatan & Pustaka & Simpulan & Keterangan \\
\hline$A$ & & Larutan Biru & & + & M. klorin \\
\hline$B$ & & Larutan Bening & & - & Tidak M. klorin \\
\hline$C$ & & Larutan Keruh & & - & Tidak M. klorin \\
\hline$D$ & + Kalium lodida & Larutan Putih & Larutan & - & Tidak M. klorin \\
\hline$E$ & + As. Klorlda encer & Larutan Biru & Biru & + & M. klorin \\
\hline$F$ & & Larutan Bening & & - & Tidak M. klorin \\
\hline$G$ & & Larutan Bening & & - & Tidak M. klorin \\
\hline$H$ & & Larutan Biru & & + & M. klorin \\
\hline
\end{tabular}

Keterangan: Merek dan produksi dirahasiakan

Berdasarkan hasil uji kualitatif di atas, maka sampel yang positif mengandung klorin yakni sampel dengan kode $\mathrm{A}, \mathrm{E}$ dan $\mathrm{H}$, dimana ketiga sampel tersebut dilanjutkan pada tahap analisis kuantitatif 
menggunakan metode Argentometri Volhard, bertujuan untuk menentukan kadar ketiga macam sampel tersebut. Hasil analisis kuantitatif seperti yang tertera pada Tabel 2, berikut:

Tabel 2. Hasil Analisis Kuantitatif kandungan klorin pada beras yang beredar di Makassar dengan metodeb Argentometri Volhard.

\begin{tabular}{cccc}
\hline $\begin{array}{c}\text { K. } \\
\text { Sampel }\end{array}$ & Replikasi & $\begin{array}{c}\text { Kadar Klorin } \\
(\mathrm{ppm})\end{array}$ & $\begin{array}{c}\text { Kadar rata-rata } \\
(\mathrm{ppm})\end{array}$ \\
\hline \multirow{3}{*}{$\mathrm{A}$} & 1 & 23,63 & \\
& 2 & 39,31 & 28,85 \\
& 3 & 23,62 & \\
$\mathrm{E}$ & 1 & 23,61 & 34,13 \\
& 2 & 39,45 & \\
\hline \multirow{2}{*}{$\mathrm{H}$} & 3 & 39,33 & 28,84 \\
& 1 & 23,62 & \\
\hline
\end{tabular}

Konsumsi beras dalam bentuk nasi merupakan kebutuhan pokok yang tidak dapat dipungkiri. Keterikatan pada beras sebagai bahan pokok dikarenakan pengolahannya mudah dan cepat, memberi kenikmatan pada saat menyantap, dan aman dari segi kesehatan karena nasi yang dikonsumsi dapat terserap oleh tubuh lebih cepat karena mengandung amilum lebih tinggi,sedangkan kadar amilopektinnya lebih rendah. Namun, keamanan ini terusik oleh adanya isu keberadaan bahan kimia berbahaya pada beras. Meskipun pemerintah (Menteri Pertanian) telah melarang penggunaan bahan kimia berbahaya pada proses penggilingan padi, huller, dan penyosohan beras, dimana termuat dalam Peraturan Menteri Pertanian No. 32/PERMENTAN /OT.140/3/2007. Beras yang dicampur bahan kimia sangat membahayakan kesehatan bahkan bisa berakibat pada kematian. Salah satu diantaranya adalah beras yang dicampur klorin. Klorin digunakan pada beras yaitu sebagai anti jamur dan efek putih sehingga beras jadi putih, bersih, mengkilap, tidak mudah rusak, bertujuan untuk meningkatkan nilai jual yang tinggi. Melakukan suatu pengolahan tertentu untuk meningkatkan kualitas beras diperbolehkan, namun tidak dilakukan dengan cara penambahan bahan kimia karena dapat memberi efek buruk terhadap kesehatan. Hasil analisis kualitatif, sampel beras diperoleh data 8 (delapan), ternyata ada 3 (tiga) sampel yang positif mengandung klorin, (Tabel 1).

Analisis kuantitatif terhadap 3 sampel yang dinyatakan positif mengandung klorin, selanjutnya dilakukan analisis kuantitatif. Kadar klorin dalam sampel ditentukan berdasarkan volume titran erak nitrat yang tersisa, dititrasi dengan larutan KSCN 0,02 N standar sampai larutan tepat berwarna kemerahan yang permanen. Lalu diamati volume Kalium Tiosianat yang digunakan, kemudian dihitung kadar klorin yaitu sebagai asam hipoklorin pada masing-masing sampel berdasarkan reaksi:

$$
\begin{aligned}
& 3 \mathrm{ClO}^{-}+2 \mathrm{Ag}^{+} \longrightarrow \mathrm{ClO}_{3}^{-}+2 \mathrm{AgCl} \\
& 3 \mathrm{~mol} \mathrm{ClO}^{-} \sim 2 \mathrm{~mol} \mathrm{Ag} \mathrm{Ag}^{+} \sim 2 \mathrm{~mol} \mathrm{AgCl} \ldots \ldots \ldots
\end{aligned}
$$

Hasil analisis kuantitatif menunjukkan kadar rata-rata klorin yang dihitung sebagai asam hipoklorin pada sampel A adalah 28,85 ppm, sampel $\mathrm{E}$ adalah 34,13 ppm dan sampel $\mathrm{H}$ adalah 28,84 ppm, (Tabel 2). Berdasarkan data di atas maka dinyatakan bahwa ketiga jenis sampel tersebut (sampel A, E dan $\mathrm{H}$ ) tidak layak konsumsi karena mengandung klorin yang melebihi nilai ambang batas yang dipersyaratkan. Sesuai hal tersebut, disarankan kepada instansi yang berwenang agar melakukan pengawasan terhadap kualitas beras dan penarikan beras yang mengandung klorin yang beredar di Pasar Tradisional Kota Makassar. Klorin yang tertelan dapat menimbulkan nyeri dan inflamasi pada mulut, kerongkongan, lambung, dan perut, serta iritasi membran mukosa perut dan pernapasan. Dalam jangka panjang bisa menyebabkan kanker hati dan ginjal.

\section{KESIMPULAN}

Berdasarkan hasil penelitian analisis klorin 8 sampel beras yang beredar di Pasar Tradisional Kota Makassar, disimpulkan: Tiga dari delapan sampel beras (sampel A, E dan H) positif mengandung klorin; Kadar klorin rata-rata pada tiga sampel dihitung sebagai asam hipoklorin yaitu sampel A kadar 28,85 ppm, sampel E kadar 34,13 ppm dan sampel H kadar 28,84 ppm; Ketiga jenis macam sampel beras tersebut tidak layak edar di masyarakat dan hendaknya di tarik oleh pihak yang berwewenang. 


\section{DAFTAR PUSTAKA}

Anonim, 2007. Beras Putih Berpemutih, (Online), (http://suara pembaruan. diakes 01 Juli 2007).

Anonim, 2007. Beras, (Online), (http://id.wikipedia.org/wiki/beras, diakses 09 Januari 2008).

Anonim, 2007. Klorin, (Online), (http:// ms.wikipedia.org/wiki/klorin, diakses 05 Agustus 2007).

Anonim, 2007. Peraturan Menteri Pertanian, (Online), No. 32/ permentan/OT.140/3/2007, (http://ogribisnis.deptan.go.id/pustaka/SK_pemutih_beras_terbaru. htm, diakses 19 Agustus 2007).

Basset, J., dkk, 1994. Buku Ajar Vogel Kimia Analisis Kuantitatif Anorganik, Edisi Keempat, Penerbit Buku Kedokteran, Jakarta, 400.

Desrosier, N.W., 1988. Teknologi Pegawetan Pangan, Universitas Indonesia Press, Jakarta, 11.

Hall, S.B.W.T., 1963. Analytical Chemistry, Qualitative Analysis, Volume 1, Ninth English Edition, John Wiley \& Sons Inc, London, 308

Haryadi, 2006. Teknologi Pengawetan Beras, Gadjah Mada University Press, Yogyakarta, 2 ; 9 ; 18-23 ; 31-34.

Hendrarno, S., 2000. Laporan Penelitian Perbaikan Kualitas Nasi Dari Beras Padi Jenis Unggul, Departemen Perindustrian/ Balai Penelitian dan Pengembangan Industri, Semarang, 5-7.

Ketut, D., Swastika, Sadra, 2012. Teknologi Panen dan Pasca Panen Padi:Kendala Adopsi dan Kebijakan Strategi Pengembangan, Jurnal Analisis Kebijakan Pertanian, vol. 10(2):331-346

Khopkar, S.M., 2007. Konsep Dasar Kimia Analitik, Universitas Indonesia Press, Jakarta, 65

Kustiari, Kusni., Sayaka, Bambang., Pasaribu, Sahat.,Teknologi Pengolahan Hasil Untuk Mengatasi Masalah Ketahanan Pangan, Makalah Pada Seminar Nasional Hasil Pertanian, Hal. 111-128

Nurmala, T.S.W., 1998. Serealia Sumber Karbohidrat Utama, Penerbit Rineka Cipta, Jakarta, 39.

Purwanto, Helmy., 2009. Teknologi Pengolahan Pertanian, Jurnal Tekn.Hasil Pertanian, vol. 5(1):15-19

Rifkowaty, E., Encik., Wardanu, P., Ancha., Aktivitas Antioksidan Sirup Buah Karamunting (Rhodomytustomentosa) Dengan Variasi Penambahan Asam Sitrat, Jurnal Tekn. Dan Industri Pertanian Indonesia, vol. 10(1)16-20

Sediaoetama, A.D., 2004. Ilmu Gizi, Jilid II, Penerbit Dian Rakyat, Jakarta, 80.

Steenis, C.G.G.J.Von, dkk, 2006. Flora, Cetakan Kesebelas, Penerbit Pradnya Peramita, Jakarta, 117.

Sunardi, 2006. 116 Unsur Kimia Deskripsi dan Pemanfaatannya, Penerbit Yarma Widya, Bandung, 86. 